\title{
Frost Risk and Rural Insurance in Brazil
}

\author{
Gustavo Bastos Braga ${ }^{1}$ (D), Hewlley Maria Acioli Imbuzeiro ${ }^{2}$, Gabrielle Ferreira Pires ${ }^{2}$, \\ Lais Rosa de Oliveira ${ }^{2}$, Rodney Alves Barbosa ${ }^{3}$, Katia de Fatima Vilela ${ }^{3}$ \\ ${ }^{1}$ Departamento de Economia Rural, Universidade Federal de Viçosa, Viçosa, MG, Brazil. \\ ${ }^{2}$ Departamento de Engenharia Agrícola, Universidade Federal de Viçosa, MG, Brazil. \\ ${ }^{3}$ Instituto Federal de Educação Ciência e Tecnologia de Minas Gerais, São João Evangelista, \\ $M G$, Brazil.
}

Received: 27 May 2021 - Accepted: 4 August 2021

\begin{abstract}
In developing countries, such as Brazil, farmers are susceptible to extreme events.The Brazilian federal government created insurance programs to mitigate extreme event effects, such as frost, called "Programa de Subvenção ao Prêmio do Seguro Rural". Frost is an atmospheric phenomenon that causes damage to plants due to low temperatures that exceed their resistance to freezing. This paper seeks to verify the risk level of frost in Brazil, connecting this information with farmers, who contracted Rural Insurance to protect themselves from this extreme event. To reduce possible biases in calculating the frost probability, this study uses two climatological databases. The majority of the Brazilian territory has very low probabilities of this phenomenon occurring. In the databases used to verify the probability of a temperature below $2{ }^{\circ} \mathrm{C}$, the data proposed by Sheffield paper, show that, in part of the Brazilian territory, there is less chance of frost than Xavier's data. Regardless of the database used, in Brazil, there are farmers who contract frost insurance in areas where the risks are close to zero.
\end{abstract}

Keyword: frost, rural insurance, agricultural production.

\section{Risco de Geada e Seguro Rural no Brasil}

\begin{abstract}
Resumo
Em países em desenvolvimento, dentre os quais o Brasil, produtores rurais são susceptíveis a eventos extremos. O governo federal brasileiro criou programas de seguro rural para mitigar os efeitos desses eventos extremos, assim como a geada, um desses programas é intitulado "Programa de Subvenção ao Prêmio do Seguro Rural". A geada é um fenômeno atmosférico que causa danos em plantas quando a baixas temperaturas excedem sua resistência ao congelamento. Este artigo procura verificar o nível de risco de geada no Brasil, ligando esses dados com as informações dos produtores que contrataram seguro rural contra esse tipo de sinistro. Para reduzir a possibilidade de vieses no cálculo do risco de geada, este artigo fez uso de duas bases de dados climatológicos com metodologias distintas. A maior parte do território brasileiro possui baixa probabilidade de ocorrência de geada. As bases de dados foram utilizadas para verificar a probabilidade de temperaturas abaixo de $2{ }^{\circ} \mathrm{C}$, os dados propostos pelo artigo de Sheffield demonstram que, em parte do território brasileiro, há menor probabilidade de geada do que os dados apresentados por Xavier. A despeito das bases de dados utilizadas, no Brasil há produtores que contratam seguros contra geada em áreas onde há riscos próximos de zero para o evento.
\end{abstract}

Palavras-chave: geada, seguro rural, produção agrícola.

\section{Introduction}

Humanity is about to experience an unprecedented challenge. The world population increase allied to its affluence has generated an increase for food demand. If this demand continues at this rate, in 2050 it will be neces- sary to have a $70 \%$ increase in food production in relation to 2009 , adding a quantitative close to 1 billion of cereal tons and 200 million tons of meat (FAO, 20091). This implies a need to optimize the use of resources and reduce losses.

Autor de correspondência: Gustavo Bastos Braga, gustavo.braga@ufv.br. 
Added to this challenge we experience a period in which, in most parts of the globe, the extreme climatic events, such as: droughts, floods, strong winds and mini -droughts, have become more frequent and tend to increase. It is estimated that the costs associated with natural disasters resulting from these extreme events have increased 14 fold since 1950 (Sivakumar, 2014). These events added a strong variability in the agricultural productivity and consequently, in the farmer's income, being even possible to hinder the continuity of their activities due to the possible losses (Kollin and Schwab, 2009).

In developing countries, as in Brazil, the small-scale farmers are the most susceptible to these kinds of events, since these farmers have in agriculture their main means of subsistence. Therefore, there is an increase in the probability of a crop failure, debt, emigration and external dependency of food (Morton, 2007).

One of the extreme events that can cause crop failure is frost. Frost is an atmospheric phenomenon that causes damage to plants due to their exposure to low temperatures that surpass their resistance to freezing, that is, below the inferior basal temperature (Williams et al. 2008). Frost occurs when the energy balance is negative (Radiation Frost), preferably in stable atmospheric conditions with a clear sky, and/or due to the entrance of a cold air mass (Advective Frost) that reduces abruptly the air temperature (Snyder and Thompson, 1987; Kalma et al., 1992; MeloAbreu, 2016).

Besides these classifications, from an agronomic point of view, two kinds of frost that cause damage to the production can be considered. One is the white frost, which occurs when the frost is accompanied by the formation of ice through the dew freezing. And the other is the black frost which occurs when the water vapor concentration is too low, therefore there is no dew to freeze, so without the previous ice formation there is a necrosis of the plant tissues. This necrosis gives a burnt aspect to the plant, which is why it is called black frost (Melo-abreu et al., 2016).

Inouye (2000) shows that the climatic changes effects over the distribution and frequency of the frosts is uncertain, however, he shows that this event can occur in a bigger volume in a region and lower periodicity in others. This meteorological phenomenon results not only in economic losses but also in social losses and damages that inflate the food prices. Thus, principally affecting the less well-off layers of society where the small farmers are usually placed (Aguiar and Mendonça, 2004).

Concerning Brazilian cases, the frost is a preoccupation for the farmers in the center-south region of the country (Wrege et al., 2018). There are historical reports that associate frost with calamities of national proportions. In 1975 in Paraná, for example, there was a frost which affected the state during decades, especially the coffee sector. For some researchers, the economy of this state can be divided in: before and after the 1975 frost (Chaddad, 2017; Rodrigues and Pelegrini, 2017).

Thus, the presence of rural risk management tools is necessary, in order to guarantee the farmer's income and permanence in his activities when there are extreme climatic events.

The agricultural insurance reimburses the farmer when there is a significant loss of the crop due to a determined external event to the property, usually a climatic event. The agricultural productions of a region climatically homogenous have a tendency to suffer impacts similar to extreme climatic events. The special correlation between the productivity of a same culture and /or of a same region, considering the climatic patterns correlated to these regions geographically close, originates from a phenomenon known as a systemic risk.

When a determined extreme climatic phenomenon occurs, many farmers, in a vast territorial extension, could be affected severely impacting the insurance companies' activities. Therefore, there is generally a systemic risk in the agricultural insurances. This factor, besides the transactions' costs involved and the oligopolistic structure of the insurance in Brazil, makes the insurance more costly, inhibiting the small farmers from obtaining it.

Aiming at solving this issue, the Brazilian federal government created programs to mitigate the effects involved. Concerning insurance, one of the main mechanisms created is the "Programa de Subvenção ao Prêmio do Seguro Rural" (Subsidization Program for the Rural Insurance Premium) (PSR). Operationally the PSR pays part of the insurance costs of the agriculture farmers, thus reducing the costs involving the insurance acquisition. Therefore, the PSR was created, among other factors, with the purpose of universalizing the rural insurance access which, traditionally, has been little claimed by the Brazilian farmers compared to other countries in the development process.

So that the farmer acquires the most suitable insurance, the PSR requires that the farmer adequates himself to the parameters of Agricultural Zoning of Climatic Risk (ZARC). Because knowledge about the edaphoclimatic conditions in a determined region is extremely important for the crop cultivated there, since the delimitation of the climatically homogeneous regions can establish the ideal climatic conditions to explore the crop with a reduced risk of productivity loss. This is a mechanism that diminishes the chances of climatic adversities for determined crops since it indicates dates for planting and delimits regions that are suitable for agricultural production. So, the PSR subsidizes only cultures that are suitable for determined properties. However, the governmental program does not observe under which climatology conditions the property is exposed. This can generate distortions as some farmers acquire insurance against improbable or null risks. 
Since Frost is not a phenomenon observed all over Brazil, it is not a preoccupation of all Brazilian farmers. In this context, this study aims at verifying the frost risks in Brazil and at which level the farmers who contracted the PSR are, in order to protect them from this extreme event.

\section{Material and Methods}

To verify the frost probability, the minimum temperature was considered as the main variable to determine the event. The culture susceptibility to frost varies according to the species in the cultivar analyzed. According to Mota (1989), the temperature of $-2{ }^{\circ} \mathrm{C}$ is the critical minimum on the plant, when the less resistant species, such as banana and rice, begin to suffer damages, while for the most resistant ones, such as the citric species, this threshold is $-4{ }^{\circ} \mathrm{C}$. Sentelhas et al. (1995) showed that the temperature measured in the meteorological shelter is usually more elevated than the one measure on the plant. In Table 1, the estimation of the minimum temperatures measured in meteorological shelters can be seen, divided in three groups: the most resistant, the intermediary and the less resistant.

Therefore, the estimation of minimum temperatures can be used as a proxy for the frost risk. In this study, the frost risk will be measured through the probability of achieving the minimum temperature to cause damage to the crop, and these results will be confronted with the data from the agricultural insurance policies.

To calculate the frost probability, this study uses Xavier et al. (2013) and Sheffield et al. (2006) climatic data bases for all Brazilian territory. The use of two databases aims to reduce eventual biases that each one could present. In both, the annual minimum temperatures were extracted for the estimation of frost risk damaging to the cultivated crops.

Xavier et al. (2013) database presents itself as a high-resolution net $\left(0,25^{\circ} \times 0.25^{\circ}\right)$ with variables of daily precipitation, evapotranspiration, maximum and minimum temperatures, solar radiation, relative humidity and wind speed. Data from 735 meteorological stations were used, being the temporal series used by the authors from 1980 to 2010 , and the interpolation being the balanced angular distance method. Now, Sheffield et al. (2006) database was composed through information from the National Centers for Environmental Prediction - National Center for Atmospheric Research (NCEP-NCAR) for modeling of precipitation variables, air temperature and radiation, and these data also included meteorological variables since1948.

Aiming at measuring the probability of a minimum temperature below a crop damage threshold, it was admitted that this is an extreme event and the extreme events distribution was applied, generally called Gumbel Distribution. This is a probability distribution model where the annual minimum values of a phenomenon are used, gradually organized. The Gumbel method is much used for the prevention of natural catastrophes and environmental statistics and its relevance is due to its impact, frequency and predictability prognostic.

The distribution of Gumbel's extreme values is represented by the following equation:

$$
f(x)=\left[\frac{1}{\beta}\right] \times \exp \left[-\left(\frac{x-\alpha}{\beta}\right)-\exp -\left(\frac{x-\alpha}{\beta}\right)\right]
$$

where $\alpha$ and $\beta$ correspond to the distribution parameters (Thom, 1966).

To calculate the minimum probability of an $x$ temperature, it is given by:

$$
P(T \leq x)=\frac{1 \int_{-\beta}^{t} \exp \left[-\frac{x-\alpha}{\beta}-\exp -\left(\frac{x-\alpha}{\beta}\right)\right]}{\beta} d y
$$

when one reduces the derivative of Eq. (2) we obtain:

$$
P(T \leq x)=\exp ^{\left[-\exp -\left(-\frac{x-\alpha}{\beta}\right)\right]}
$$

Although the Gumbel distribution use is not unanimous among researchers, the conclusions from the works of Camargo et al. (1993) and Astolpho et al. (2005) are highlighted. As the authors evaluated Gumbel's model for monthly and annual minimum temperatures, they obtained satisfactory results between the estimated and observed frequencies. Melo-abreu et al. (2016) also cite Gumbel's extreme values distribution to calculate frost probability. Wrege et al. (2018) also use Gumbel Distribution as a frost prediction model in Brazilian territory, obtaining satisfactory results.

Thus, the probability of temperatures equal or smaller than the limit for damage in each crop culture, was calculated using both databases shown. Besides this, the results were crossed with the geo-referenced data of far-

\begin{tabular}{|c|c|c|}
\hline \multicolumn{3}{|c|}{ Minimum temperature estimated in meteorological shelter } \\
\hline $4^{\circ} \mathrm{C}(+)$ Sensitive more resistant & $2{ }^{\circ} \mathrm{C}$ sensitive intermediary & $0{ }^{\circ} \mathrm{C}(-)$ Sensitive Less resistant \\
\hline Banana, Potato, Beans, Greenery, Papaya and Tomato & Coffee, Soy beans, Sugar cane, Mango and Wheat & Orange, Apple and Pear \\
\hline
\end{tabular}
mers with insurance policies that cover frost sinister

Table 1 - Minimum temperature measured in shelter to cause culture damage.

Source: Adapted from INPE, 2019. 
aiming at verifying if there is coherence in the insurance contracting. These last data were available by a covenant with the Supply, Livestock and Agricultural Ministry MAPA (2017).

\section{Results and Discussion}

The majority of rural insurance via PSR in Brazil are for soybean, corn $2^{\text {nd }}$ harvest, grape, wheat, cultures that are considered medium sensitive to frost. It is also observed that, except for beans, the policies which were activated due to frost sinister are of these types of crops, according to Table 2 . The temperature threshold for damages to these cultures is $2{ }^{\circ} \mathrm{C}$ (INPE, 2019).

As shown in the data, in 2016, only in the cultures of Coffee, Sugar Cane, Barley, Wheat, Grape and Corn $2^{\text {nd }}$ harvest, known as little harvest corn, frost was activated . This last concentrates the majority of activations and also shows a greater activation percentage. In 2017, the activations were in similar cultures. In relation to 2016, there were no activations for sorghum and sugarcane, and there was only a single activation for forest. Now, the activation numbers were very distinct. Wheat begins to concentrate the greatest number of activations and, in percentage terms, barley stands out with an activation of $11,69 \%$ of the frost insurance. Despite not having activation data for 2018 , it is possible to verify that the greater number of activations in the previous years does not show an increase in the demand for insurance in the following year. Since, in cultures with greater activations, as elevated activations, such as wheat, corn $2^{\text {nd }}$ harvest, barley and grape, had a reduction in the contracting in some of the years analyzed.

A large part of the cultures do not have activated insurance in any of the years analyzed, for example the summer cultures of soybean and corn $1^{\text {st }}$ harvest. To understand if there are relevant frost risks for these farmers who do not activate the event, the probabilities of temperatures below $2{ }^{\circ} \mathrm{C}$ were calculated. In Fig. 1, the probability of temperatures below or equal to $2{ }^{\circ} \mathrm{C}$ are shown, using the Xavier et al. (2013) and Sheffield et al. (2006) databases, considering Gumel distribution.

In general, Sheffield et al. (2006) data are more optimistic regarding the extreme minimum temperatures probabilities. The main distinctions in the probabilities of temperatures below $2{ }^{\circ} \mathrm{C}$ are in the south coast of Brazil, where the Sheffield et al. (2006) data showed substantially smaller probabilities. There still is the south region of Minas Gerais State and also the south of Mato Grosso do Sul State, where the database provided by Xavier et al. (2013) shows a larger area with a probability above 50\% of temperatures below $2{ }^{\circ} \mathrm{C}$. The presented distinctions can be due to the information sources used by the authors, besides the period of time analyzed by Sheffield et al. (2006) being longer. However, according to what is shown in Fig. 2, the database has ample convergence with a great part of the analyzed pixels with differences close to 0 .

Table 2 - Insurance that had coverage against frost per year, activation and culture.

\begin{tabular}{|c|c|c|c|c|c|c|c|}
\hline \multirow[t]{2}{*}{ Culture } & \multicolumn{3}{|c|}{ Policies in 2016} & \multicolumn{3}{|c|}{ Policies in 2017} & \multirow{2}{*}{$\begin{array}{c}\text { Policies in } 2018^{*} \\
\text { Insured }\end{array}$} \\
\hline & $\begin{array}{l}\text { Insured non } \\
\text { activated }\end{array}$ & $\begin{array}{c}\text { Insured } \\
\text { activated }\end{array}$ & $\begin{array}{l}\text { Activation } \\
\text { percentage }\end{array}$ & $\begin{array}{l}\text { Insured non } \\
\text { activated }\end{array}$ & $\begin{array}{c}\text { Insured } \\
\text { activated }\end{array}$ & $\begin{array}{l}\text { Activation } \\
\text { percentage }\end{array}$ & \\
\hline Cotton & 10 & - & - & 10 & - & - & 6 \\
\hline Rice & 429 & - & - & 479 & - & - & 291 \\
\hline Oat & 5 & - & - & - & - & - & - \\
\hline Potato & 13 & - & - & 33 & - & - & 17 \\
\hline Coffee & 717 & 14 & $1.92 \%$ & 778 & 2 & $0.26 \%$ & 769 \\
\hline Sugar Cane & 679 & 7 & $1.02 \%$ & 765 & - & - & 489 \\
\hline Barley & 203 & 3 & $1.46 \%$ & 136 & 18 & $11.69 \%$ & 51 \\
\hline Beans & 140 & 6 & $4.11 \%$ & 151 & 7 & $4.43 \%$ & 243 \\
\hline Forest & 49 & - & - & 45 & 1 & $2.17 \%$ & 42 \\
\hline Corn $1^{\text {st }}$ harvest & 1.589 & - & - & 1.017 & - & - & 879 \\
\hline Corn $2^{\text {nd }}$ harvest & 7.991 & 1211 & $13.16 \%$ & 7.413 & 54 & $0.72 \%$ & 11.482 \\
\hline Soybean & 20.926 & - & - & 18.762 & - & - & 17.543 \\
\hline Sorghum & 135 & 2 & $1.46 \%$ & 37 & - & - & 7 \\
\hline Tomato & 74 & 2 & $2.63 \%$ & 64 & 1 & $1.54 \%$ & 102 \\
\hline Wheat & 6.076 & 147 & $2.36 \%$ & 3.121 & 280 & $8.23 \%$ & 3.948 \\
\hline Grape & 1.111 & 129 & $10.40 \%$ & 1.219 & 50 & $3.94 \%$ & 1.095 \\
\hline Total & 40.147 & 1521 & $3.65 \%$ & 34.030 & 413 & $1.20 \%$ & 36.955 \\
\hline
\end{tabular}

Until the moment of this research there was no data about the insurance activation in 2018. 


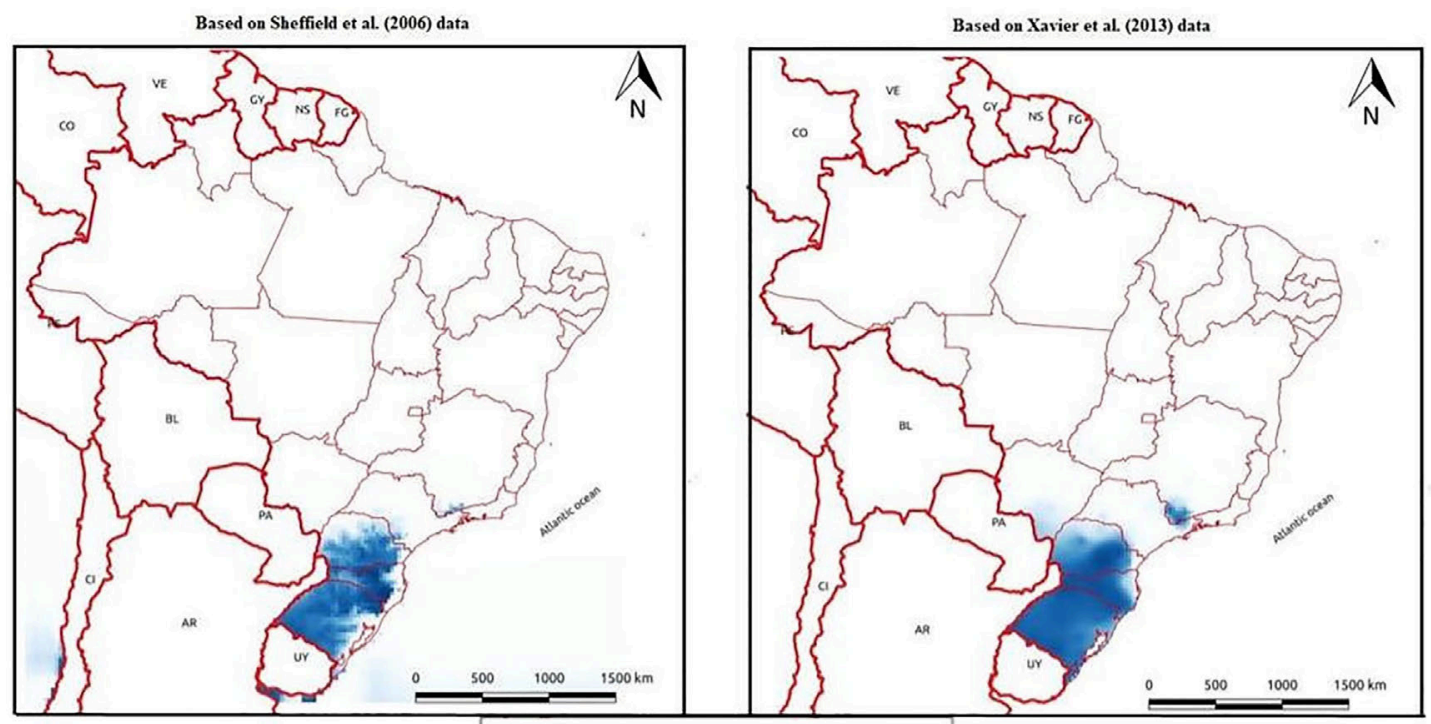

\begin{tabular}{|l|} 
Probability of temperatures below $2^{\circ} \mathrm{C}$ \\
$\square$ \\
$1.01 \mathrm{e}-10$ \\
0.11 \\
0.22 \\
$=0.33$ \\
$=0.44$ \\
$=0.55$ \\
0.66 \\
$=0.77$ \\
$=0.88$ \\
0.99
\end{tabular}

Figure 1 - Probability of temperatures below or equal to $2{ }^{\circ} \mathrm{C}$ according Xavier et al. (2013) and Sheffield et al. (2006) databases.

As can be seen in the Fig. 1, positive values indicate that the model based on Xavier et al. (2013) showed a greater probability of temperatures below probability $2{ }^{\circ} \mathrm{C}$. The risk of minimum temperatures damaging to the medium sensitive cultivars are centered in the south of the country in specific parts of São Paulo, Mato Grosso do Sul and Minas Gerais States, confirming the study made by Aguiar and Mendonça (2004) and Wrege et al. (2018). However, the agricultural insurances, subsidized by PSR,

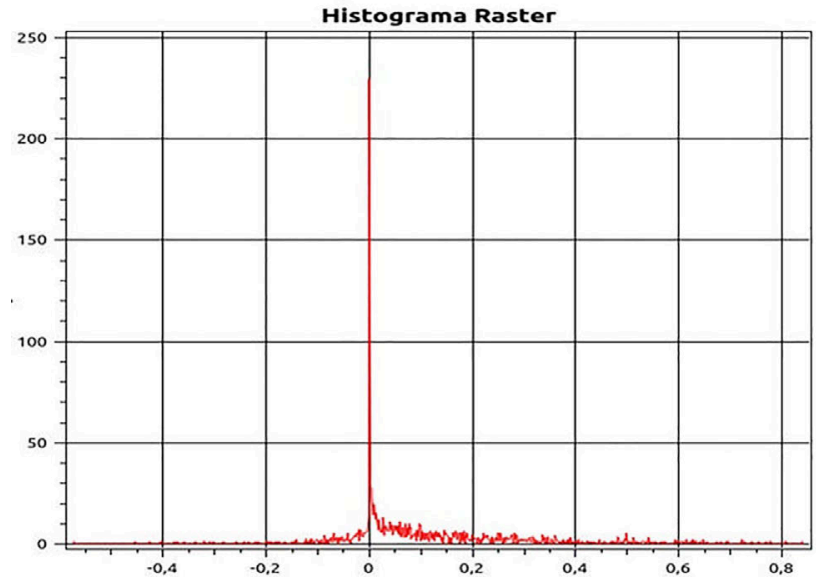

Figure 2 - Histogram of the differences between the results based on Xavier et al. (2013) and Sheffield et al. (2006). that cover frost risk, in 2016 and 2017 are spread throughout all Brazilian regions, as shown in Fig. 3.

As can be verified, many farmers provide themselves with policies that cover an event where the probability of it occurring is smaller than $1 \times 10^{-10} \%$, and also in many areas, temperatures below $2{ }^{\circ} \mathrm{C}$ have never occurred in the database history. And in 2017 and 2018 there was an expansion of insurance against frost in areas where there were very little probabilities of the phenomenon happening. This distortion is due to the fact that many policies cover multiple risks, the so-called "multirisk" (MAPA, 2017). Thus, this shows that the frost risks, additionally covered, are so rare that the inclusion of the sinister is irrelevant in the increase of the farmer's safety.

On Table 3, the risks of temperatures below $2{ }^{\circ} \mathrm{C}$ percentiles per farmer that contracted insurance that cover the frost extreme event, are shown.

According to Table 2 in 2016, $10 \%$ of the farmers that contracted insurance that covers frost, did not effectively have the risk of such an event to occur, and more than half of the farmers, even considering the maximum risks of both databases, had less than $40 \%$ chance of damaging temperatures occurring. In 2017, there is an improvement in this scenario; however, even so, more than half of the farmers had less than $50 \%$ probability of being exposed to temperatures below 2 degrees centigrade. Yet, 2018 data represent a substantial increase in 

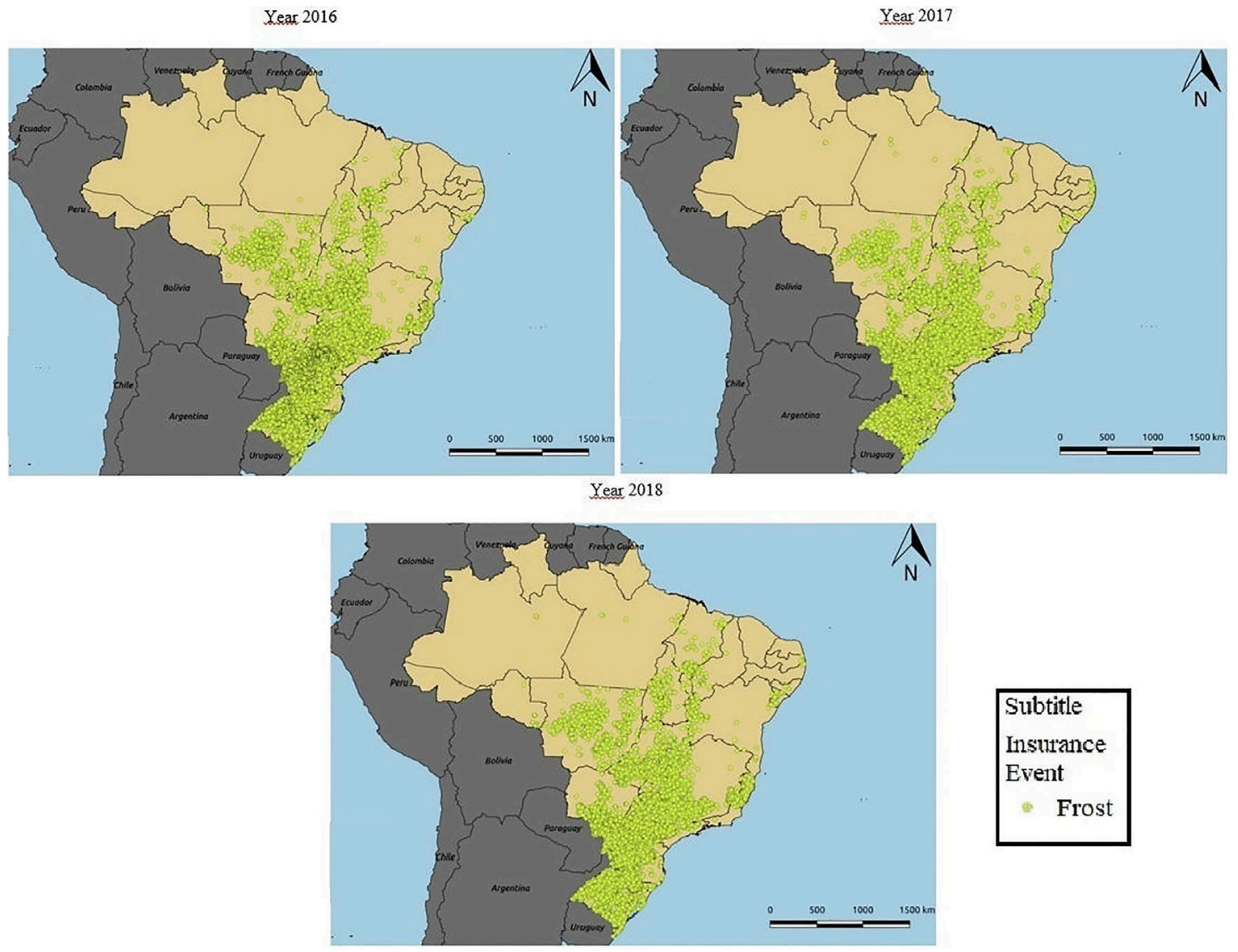

Figure 3 - Properties that have policies that covered frost sinister. Source: MAPA (2018).

Table 3 - Probability of temperatures below $2{ }^{\circ} \mathrm{C}$ per farmer that contracted insurance that covers the frost in 2016.

\begin{tabular}{|c|c|c|c|c|c|c|c|c|}
\hline & & \multicolumn{7}{|c|}{$\begin{array}{c}\text { Percentiles } \\
\text { Year } 2016\end{array}$} \\
\hline & & 5 & 10 & 25 & 50 & 75 & 90 & 95 \\
\hline \multirow[t]{3}{*}{ Weighted Average } & Xavier & $>0.0000$ & $>0.0000$ & 0.1218 & 0.3622 & 0.7466 & 0.8644 & 0.8811 \\
\hline & Sheffield & $>0.0000$ & $>0.0000$ & 0.0249 & 0.2098 & 0.6604 & 0.8193 & 0.8566 \\
\hline & Maximum & $>0.0000$ & $>0.0000$ & 0.1267 & 0.3907 & 0.7677 & 0.8674 & 0.8863 \\
\hline \multirow[t]{4}{*}{ Tukey Test } & Xavier & & & 0.1218 & 0.3622 & 0.7466 & & \\
\hline & Sheffield & & & 0.025 & 0.2098 & 0.6604 & & \\
\hline & Maximum & & & 0.1267 & 0.3907 & 0.767 & & \\
\hline & & Year 2017 & & & & & & \\
\hline \multirow[t]{3}{*}{ Weighted Average } & Xavier & 0.0296 & 0.0892 & 0.1852 & 0.5056 & 0.8193 & 0.8650 & 0.8785 \\
\hline & Sheffield & 0.0002 & 0.0109 & 0.0742 & 0.2595 & 0.6962 & 0.8271 & 0.8596 \\
\hline & Maximum & 0.0380 & 0.1057 & 0.1978 & 0.5187 & 0.8211 & 0.8681 & 0.8864 \\
\hline \multirow[t]{4}{*}{ Tukey Test } & Xavier & & & 0.1852 & 0.5056 & 0.8193 & & \\
\hline & Sheffield & & & 0.0742 & 0.2595 & 0.6962 & & \\
\hline & Maximum & & & 0.1978 & 0.5187 & 0.8211 & & \\
\hline & & Year 2018 & & & & & & \\
\hline \multirow[t]{2}{*}{ Weighted Average } & Xavier & $>0.0000$ & $>0.0000$ & 0.1218 & 0.2687 & 0.6279 & 0.8523 & 0.8679 \\
\hline & Sheffield & $>0.0000$ & $>0.0000$ & 0.0299 & 0.1506 & 0.5211 & 0.8016 & 0.8463 \\
\hline
\end{tabular}


Table 3 - continued

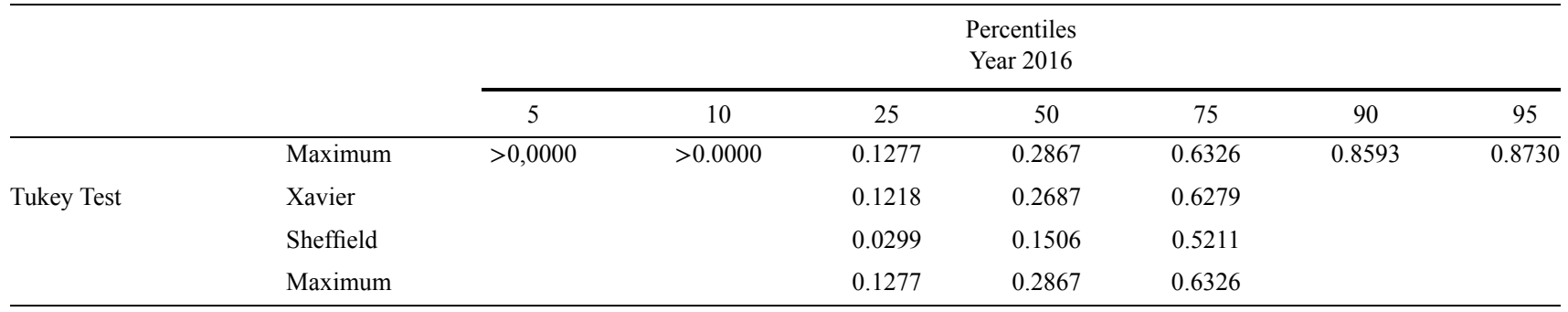

insurance in areas where the risk of frost is smaller. In fact, more than 50 percent of the farmers who were covered against frost had less than $30 \%$ chances of being exposed to temperatures that, potentially, could generate damage to production.

To verify the model effectiveness, the average for risks per culture was calculated comparing groups that activated or that were not affected by the frost sinister. To avoid these biases due to low data volume, only the cul- tures with more than 30 activations in the analyzed year were considered. In this analysis 2018 was not included because of the lack of data about activation up to the time of this research. Therefore, the calculations consider wheat, corn $2^{\text {nd }}$ harvest and grape; the results are shown in Table 4.

According to the data shown in Table 4, the models point out higher probabilities of temperatures below $2{ }^{\circ} \mathrm{C}$ for the policies which were activated. The only exception

Table 4 - Probability of temperatures below 2 degrees Celsius and insurance activation.

\begin{tabular}{|c|c|c|c|c|c|}
\hline \multicolumn{6}{|c|}{ Year 2016} \\
\hline There was insurance activation & Model & Culture & $\mathrm{N}$ & Average & Standard Deviation \\
\hline \multirow[t]{9}{*}{ No } & Maximum risk & Corn $2^{\text {nd }}$ harvest & 7991 & 0.2013 & 0.2227 \\
\hline & & Wheat & 6076 & 0.6181 & 0.2515 \\
\hline & & Grape & 1111 & 0.8492 & 0.0299 \\
\hline & Xavier & Corn $2^{\text {nd }}$ harvest & 7991 & 0.1951 & 0.2207 \\
\hline & & Wheat & 6076 & 0.5981 & 0.2637 \\
\hline & & Grape & 1111 & 0.8361 & 0.0237 \\
\hline & Sheffield & Corn $2^{\text {nd }}$ harvest & 7991 & 0.1193 & 0.1731 \\
\hline & & Wheat & 6076 & 0.5379 & 0.2606 \\
\hline & & Grape & 1111 & 0.7973 & 0.0945 \\
\hline \multirow[t]{9}{*}{ Yes } & Maximum risk & Corn $2^{\text {nd }}$ harvest & 1211 & 0.3175 & 0.1676 \\
\hline & & Wheat & 147 & 0.6642 & 0.1890 \\
\hline & & Grape & 129 & 0.8719 & 0.0358 \\
\hline & Xavier & Corn $2^{\text {nd }}$ harvest & 1211 & 0.3037 & 0.1702 \\
\hline & & Wheat & 147 & 0.6460 & 0.2042 \\
\hline & & Grape & 129 & 0.8547 & 0.0383 \\
\hline & Sheffield & Corn $2^{\text {nd }}$ harvest & 1211 & 0.2082 & 0.1571 \\
\hline & & Wheat & 147 & 0.5975 & 0.2063 \\
\hline & & Grape & 129 & 0.7891 & 0.0939 \\
\hline & & Year 2017 & & & \\
\hline \multirow[t]{5}{*}{$\overline{\text { No }}$} & Maximum risk & Corn $2^{\text {nd }}$ harvest & 7137 & 0.3140 & 0.2062 \\
\hline & & Wheat & 3121 & 0.6048 & 0.2722 \\
\hline & & Grape & 1219 & 0.8487 & 0.0297 \\
\hline & Xavier & Corn $2^{\text {nd }}$ harvest & 7122 & 0.3059 & 0.2069 \\
\hline & & Wheat & 3113 & 0.5802 & 0.2891 \\
\hline
\end{tabular}


Table 4 - continued

\begin{tabular}{|c|c|c|c|c|c|}
\hline \multicolumn{6}{|c|}{ Year 2016} \\
\hline There was insurance activation & Model & Culture & $\mathrm{N}$ & Average & Standard Deviation \\
\hline & & Grape & 1219 & 0.8352 & 0.0231 \\
\hline & Sheffield & Corn $2^{\text {nd }}$ harvest & 6810 & 0.1950 & 0.1791 \\
\hline & & Wheat & 3119 & 0.5333 & 0.2687 \\
\hline & & Grape & 1219 & 0.8018 & 0.0929 \\
\hline \multirow[t]{9}{*}{ Yes } & Maximum risk & Corn $2^{\text {nd }}$ harvest & 54 & 0.5898 & 0.1741 \\
\hline & & Wheat & 280 & 0.6422 & 0.17445 \\
\hline & & Grape & 50 & 0.8678 & 0.0331 \\
\hline & Xavier & Corn $2^{\text {nd }}$ harvest & 54 & 0.5711 & 0.1728 \\
\hline & & Wheat & 280 & 0.6291 & 0.1744 \\
\hline & & Grape & 50 & 0.8485 & 0.0230 \\
\hline & Sheffield & Corn $2^{\text {nd }}$ harvest & 54 & 0.5026 & 0.2394 \\
\hline & & Wheat & 280 & 0.5761 & 0.1956 \\
\hline & & Grape & 50 & 0.8581 & 0.0483 \\
\hline
\end{tabular}

was in the Grape culture for the risks calculated with the Sheffield data for 2016. However, carrying out the $t$ test for independent samples, all the culture crossings, database and year showed a significant $1 \%$, excepting this case that showed a p-value of 0.11 . Thus, the results support the strength of the frost risk prediction model using Gumbel distribution of the extreme minimum temperatures, as already observed by Camargo et al. (1993), Astolpho et al. (2005), Melo-abreu et al. (2016) and Wrege et al. (2018).

\section{Conclusions}

Frost is a phenomenon that brings economical losses in agricultural production. In Brazil, in a great part of its territory, the probabilities of this phenomenon occurring are extremely small. The results show that in the states of Rio Grande do Sul, Santa Catarina, Paraná and parts of São Paulo, Minas Gerais and Mato Grosso do Sul there are relevant probabilities of frost.

In the database used to verify the probability of temperatures below $2{ }^{\circ} \mathrm{C}$, a critical temperature critical that could cause damages in great part of the cultures cultivated in the country, the data proposed by Sheffield et al. (2006) showed, in part of the Brazilian territory, fewer probabilities than the data elaborated by Xavier (2013). Nevertheless, there is a great convergence in the results of both works. The use of these data and the Gumbel distribution show satisfactory results to preview frosts. In the analyzed cultures, in 2016 and 2017, it was observed that the average of probabilities for temperatures below two degrees centigrade, in those properties that did not activate insurance against frost, was significantly smaller.

Still concerning rural insurances, the contracting of insurances that cover this sinister are all over the country, including areas where the risk is near zero. The multirisk insurance modality ends up ensuring properties with practically no risk against frost. In general, few cultures have activated the insurance in the studied years, standing out corn $2^{\text {nd }}$ harvest, wheat and grape, in 2016 and, barley, wheat and grape in 2017. Comparing the data of 2016 and 2017, a slight evolution is observed, with contracts with risks a little higher. However, there was a decrease in the activation percentage in this biennial; in this same period, there is a reduction of the contracts that have coverage against frost.

Future studies should analyze if in other climatological risks the probability of occurring a sinister risk for insured ones is low, and if this occurs in multi-risks insurance. Furthermore, other models of frost probability detection can be used, aiming at improving, and potentially, subsidizing the information of the one contracting the rural insurance.

\section{References}

AGUIAR, D.; MENDONÇA, M. Climatologia das geadas em Santa Catarina. Simpósio Brasileiro de Desastres Naturais. Florianópolis: GEDN/UFSC, 2004.

AMBENJE, P.; KARL, T.R.,; KUNKEL, K.E.; EVANS, J.L.; EASTERLING D.R.; GROISMAN, P.Y. Observed variability and trends in extreme climate events: A brief review. Bulletin of the American Meteorological Society, v. 81 n. 3, p. 417-425, 2002.

ASTOLPHO, F.; DE CAMARGO, M.B.P.; PEDRO, M.J.; PALLONE FILHO, W.J.; BARDIN, L. Regionalização de riscos de ocorrência de temperaturas mínimas absolutas anuais para o estado de São Paulo com base em modelos probabilísticos e digitais de elevação. Bragantia, v. 64 n. 1, p. 139-148, 2005. 
CAMARGO, A.P. Freqüências das geadas excepcionais como as de julho de 1975. Seminário Internacional Sobre Climatologia no Hemisfério Sul, p. 1-3, 1977.

CAMPOS, C.G.C.; MALINOVSKI, L.I.; MARENGO, J.A.; OLIVEIRA, L.V.; VIEIRA, H.J.; SILVA, A.L. The impact of climate projections when analyzing the risk of frost to viticulture in the southern region of Brazil. Acta Horticulturae, v. 1188, p. 165-172, 2017.

CHADDAD, F. Economia e Organização da Agricultura Brasileira. São Paulo: Elsevier Brasil: 2017.

FOOD AND AGRICULTURE ORGANIZATION. How to Feed the World in 2050. Rome: FAO, 2009

INOUYE, D.W. The ecological and evolutionary significance of frost in the context of climate change. Ecology Letters, v. 3, n. 5, p. 457-463, 2000.

INSTITUTO NACIONAL DE PESQUISAS ESPACIAIS. Geadas. Retrieved from http://agricultura.cptec.inpe.br/geada. shtml, 2011.

KOLLIN, C.; SCHWAB, J.C. Conclusions and recommendations. In: Natural Disasters and Extreme Events in Agriculture, p. 351-355, 2009.

MELO-ABREU, P.; VILlalobOS, F.J.; MATEOS, L. Principles of Agronomy for Sustainable Agriculture. Berlin: Springer, 2016.

MINISTÉRIO DA AGRICULTURA. Acordo de Cooperação Técnica n. /2017. Brasília: SPA/MAPA, 2017.

MORTON, J.F. (2007). The impact of climate change on smallholder and subsistence agriculture. Proceedings of the National Academy of Sciences, v. 104 n. 50, p. 1968019685.

MOTA, F.S. Meteorologia Agrícola. São Paulo: Nobel, 1989.

PINTO, H.S.; ASSAD, E.D.; ÁVILA, A.M.H.; CEPAGRI, U.; BRASIL, S.P. Global warming and future brazilian agri- culture scenarios. Annalen der Meteorologie, v. 1 n. 1, p. 223-226, 2005.

RODRIGUES, J.P.P.; PELEGRINI, S.C.A. Imprensa e memória: A geada negra de 1975. Revista Labirinto, v. 27 n. 1, p. 210-222, 2017.

SENTELHAS, P.C.; ORTOLAN, A.A.; PEZZOPANE, J.R.M. Estimativa da temperatura mínima de relva e da diferença de temperatura entre o abrigo e a relva em noites de geada. Bragantia, v. 54 n. 2, p. 437-445, 1995.

SIVAKUMAR, M.V.K. Impacts of Natural Disasters in Agriculture: An Overview. World Meteorological Organisation, Geneva, p. 1-2, 2014.

SIVAKUMAR, M.V.K. Impacts of natural disasters in agriculture, rangeland and forestry: an overview. Natural Disasters and Extreme Events in Agriculture, v. 99 n. 1, p. 122, 2018.

SNYDER, R.L.; MELO-ABREU, J.P. Frost protection: Fundamentals, practice and economics. In: Environment and Natural Resources Series. v. 1. Rome: FAO, p. 112, 2005.

WREGE, M.S.; FRITZSONS, E.; SOARES, M.T.S.; PRELAPÂNTANO, A.; STEINMETZ, S.; CARAMORI, P.H.; PANDOLFO, C. Risco de ocorrência de geadas na região centro-sul do Brasil. Revista Brasileira de Climatologia, v. 22, n. 1, p. 524-553, 2018.

XAVIER, A.C., KING, C.W.; SCANLON, B.R. Daily gridded meteorological variables in Brazil (1980-2013). Int. J. Climatol., v. 36 n. 6, p. 2644-2659, 2016.

License information: This is an open-access article distributed under the terms of the Creative Commons Attribution License (type CC-BY), which permits unrestricted use, distribution and reproduction in any medium, provided the original article is properly cited. 